\title{
Issues concerning women
}

\section{The development of the women's movement}

Descriptions of the legislation passed to improve the status of women

Review and analysis of remaining issues concerning the status of women

\section{BACKGROUND}

\section{Women's emancipation}

Although the cause of improvement in the status of women can be traced back into the nineteenth century, the effective story must begin with the time when women achieved the right to vote after a sustained campaign of civil disobedience and parliamentary campaigning. Women over 30 years old were allowed to vote in 1918 and 21-year olds (the age of male suffrage) followed in 1928.

But women's suffrage was not the breakthrough which it might at first appear. It had been hoped, and even assumed, that once women were given a political voice many other benefits would automatically follow. With politicians now accountable to women and seeking their votes, surely they would begin to listen to demands for further concessions. Furthermore, the movement had been almost exclusively middle class in character. There was little interest in the plight of women in working-class families such as lack of education, poor career prospects and the common burden of large families in poor circumstances of health and housing.

The truth was that, in the first half of the twentieth century, the problems of women, their rights and status, were too deeply rooted to be solved merely by access to the political system. The political parties did not, as had been expected, place women's issues on their political agenda, there was no avalanche of women entering the House of Commons and the extra-parliamentary movement seemed to wither after it achieved its primary goal.

Sandwiched between the two stages in the enfranchisement of women came an Act which had almost as much potential significance. This was the Sex 
Disqualification (Removal) Act of 1919. This legislation opened up both the universities and the professions to women. There had previously been a range of prohibitions on women's ability to pursue advanced careers. In the event, relatively few women entered politics for many years to come, but the opening up of higher education and the professions had a more immediate impact.

Nevertheless, progress in the early part of the twentieth century remained slow. Between 1928 and the 1960s, therefore, the women's movement retreated into the background of British politics. When it re-emerged in the 1960s, the impetus came from the USA.

\section{Radical feminism and the New Left}

A crucial event in the development of the modern women's movement was the publication of an American book - The Feminine Mystique - written by Betty Friedan in 1963. Friedan's work was a devastating criticism on a culture which had come to be completely dominated by men. She demonstrated that 'patriarchy' was in fact a complete system of oppression of women. Women suffered not only discrimination in fields such as employment, education and the arts, they were also being denied opportunities to realise their full potential. From the moment of birth, she complained, gender stereotypes are encouraged which suggest that men are superior. This went much further than the women's movement had ever gone before, representing a radical analysis of a maledominated society and implying similarly radical measures to combat patriarchy.

In the early 1960s the infant women's movement was part of a broader phenomenon which came to be known as the 'New Left'. This essentially leftwing political philosophy saw society as polarising into two large groups. The first contained those who were enjoying all the benefits of the prosperous consumer society. They were in the mainstream of a mass culture which was the result of fully developed capitalism. The other was a collection of groups who had become alienated from the mass culture. They were denied many of its benefits and made to feel outsiders. The principal examples of alienated cultures were ethnic minorities, the poor, disaffected youth, gays and, of course, women. In each case radical, often revolutionary, movements grew up in the 1960s.

The women's movement, inspired by Friedan's work spread into Europe. Its key figures were Kate Millet and Shulamith Firestone in the USA, Germaine Greer in Britain and Simone de Beauvoir in France. In varying degrees these campaigners recommended militant measures to liberate women from the control of the men. They suggested women should separate themselves entirely by forming their own communes or should engage in subversive activities to undermine patriarchy very much as the suffragettes had done fifty 
years before. These radical feminists, as they came to be known, argued that legislation to grant women equal opportunities and higher status would not be adequate. The problem of women's status would require a radical transformation of society.

During the 1970s the radical feminist movement began to weaken and become dissipated. This was, to some extent, part of a general decline in the strength of the new left. However, it was also overtaken by the fact that a wide range of concessions were appearing. These were designed to meet some of the clearer demands of the women's movement, but also had the effect of splitting the women's movement. In the 1970s it was a new liberal kind of feminism which was gaining the ascendancy.

\section{Liberal feminism}

Liberal, as opposed to radical, feminists were not revolutionaries. They wished to see reform, but did not challenge the fundamental order. In other words they believed it would be possible to achieve equal status and liberation for women through changes within the existing social order. Three important developments in Britain (all of which were also supported by the militant feminists) occurred in the 1960s and 1970 to give a boost to the liberal movement and set it on the way to further successes.

The birth control pill became widely available after 1967. This heralded in a period of sexual liberation for women, which became the centrepiece of a more general youth liberation movement (the so-called 'hippy' or 'flower power' era). It resulted in two developments. The first was that married women were able to take control themselves of family planning and so rely less on men. This meant that women were able better to control the size of their family and/or delay childbirth to a later age, thus enabling them to pursue a career. The second was that unmarried women were more sexually liberated as they could protect themselves easily from fear of pregnancy. Of course, for many this was an undesirable result, but it was welcomed wholeheartedly by all feminists.

Also in 1967 the Abortion Act was passed. For the first time abortion became legal in Britain (England and Wales only at first). This had an immediate effect on the illegal abortion industry which resulted in many health problems and even deaths for young women. More importantly here, however, abortion became the flagship issue for women. In practical terms it stood alongside the birth control pill as a liberating force. But it was much more than that. Abortion became symbolic of women taking control of their own bodies and health. Feminists saw the prohibition on abortion as a feature of a male-dominated society. Put simply, it was men deciding what was best 
for women on their behalf. So the legality of abortion became a vital gesture of liberation.

The Divorce Law Reform Act of 1970 made it much easier for women (incidentally as well as men) to obtain a divorce. It established that there was only one ground for divorce which was the irretrievable breakdown of the marriage. The Act established that a two-year separation (five years if the divorce was contested) constituted a breakdown. Not only did this liberate many women who were trapped in unhappy and unfulfilling marriages, it also helped to take away the social stigma which used to surround divorced women. Like the other two reforms described above, easier divorce had its opponents who saw it as a retrograde step in terms of morality and social stability. But also like the other two feminists welcomed the liberalisation of the divorce laws as a key step forward for women.

In the same year the Matrimonial Proceedings and Property Act gave courts the power to grant property to divorcing women and to force husbands to make financial provision for ex-wives and their children. So, not only was it easier for women to obtain a divorce, but the financial consequences would also be less severe.

The scene was now set for even more important battles to be fought by the feminist movement. These were the issues of equal pay and the outlawing of sex discrimination in a wide variety of fields.

\section{EQUAL PAY}

By 1970 there had developed a crescendo of women's protests against unequal treatment of women in the workplace. There were significant differences in the pay of women compared with men. The Equal Pay Act of 1970 attempted to correct this situation. At first sight it seemed to have solved the problem, but it turned out to be a flawed measure.

The Act stated that women should be paid the same wage as men if they were doing the same job. However employers were able to avoid the legislation simply by giving women different job titles or by slightly altering the nature of their work. In this way it could be claimed that men and women were not doing the same job in the strict sense of the word. Two more Acts were needed to tidy up the equal pay legislation.

The Sex Discrimination Act of 1975, which is described more fully below, established that if a woman's work was effectively the same as that done by a man then she was entitled to equal pay. In 1984 the Equal Pay 
(Amendment) Act was a final attempt to close up all the loopholes. It was passed to bring Britain into line with European Union legislation (which was to be binding in the UK). This introduced a new test for equal pay. Provided work is of equal value, even if it is different in nature, women should be paid the same as men (and vice versa, of course). The 1984 Act was the most radical of all the measures on pay as it was an attempt to establish total equality for women in the workplace

But equal pay was only one of the issues concerning the status of women. It was seen as a symbol of wider discrimination which was taking place, but on its own it was inadequate. A broader, all-embracing measure was needed. This arrived in 1975.

\section{THE SEX DISCRIMINATION ACT 1975}

The new Labour government which came to power in 1974 was determined to complete the radical reforms concerning equal opportunities which had been started in the 1960s. It therefore passed the landmark Sex Discrimination Act as a priority. The Act contained two main elements as shown in the box.

\section{Sex Discrimination Act 1975}

1 Outlawed discrimination on the grounds of sex (i.e. for either men or women, but not including homosexuals) in a wide variety of activities.

2 Established the Equal Opportunities Commission whose role was both to administer the existing legislation and to further the issue of sexual equality into the future.

Since 1975 many cases have been brought by individuals and by the Equal Opportunities Commission which have 'filled out' the basic laws. This body of 'case law' has established some of the following principles:

- Even when an employer is not discriminating directly against women, he may be accused of engaging in practices which have the effect of discriminating. For example if an employer will not employ people who are lone parents, this will have the effect of tending to discriminate against women. It is also not permitted to refuse to employ a woman on the grounds that she is likely to become pregnant and so take too much time off work.

- If a woman can prove that she has equal qualifications to men and yet is continually passed over for promotion, a case may be made that the employer is discriminating.

- If women are doing the same work as men, but have a different job title, they must not be discriminated against in terms of pay.

- In the provision of services such as insurance, bank loans, mortgages and rental agreements, women must be treated on an equal basis to men. 
These cases are a sample of the way in which the sex discrimination laws work. They are also reinforced by the European Court of Justice and the European Court of Rights which ensures that women are given equal treatment at work, in terms of working conditions and in welfare benefits. The passage of the Human Rights Act in 1999 made it easier for women to claim discrimination under the European Convention on Human Rights. They may, since then, bring a case in the British courts. This saves both time and money.

\section{REMAINING ISSUES}

The battles for equal treatment for women in most aspects of life have been won. However, there remain a number of areas, often which are less clear, where women do not feel they have achieved equality or justice. The main examples are described below:

\section{Sexism}

The term 'sexism' refers to a cultural attitude towards women which implies that they are inferior or that they have a limited role to play in modern society. Sexist attitudes are, claim campaigners, carried in such institutions as schools, TV and radio, the press, sport and entertainment. It is further argued that, as long as sexist attitudes persist, real, concrete examples of discrimination will follow. Furthermore, the more extreme examples of sexism may lead to the degradation of women.

Pornography, hard and soft, and the gratuitous display of women in sexual poses to advertise goods are seen as particularly undesirable examples of sexism. Led by Cabinet Minister Clare Short, women's groups have sought stricter laws against pornography and so-called 'page three girls'.

The problem with sexism is that it is difficult to tackle it with legislation. All that can be done is that women's groups, including the Equal Opportunities Commission, to raise awareness of the problem and seek to combat it through education and public campaigning. Moreover, the anti-sexism movement has had to face accusations of 'political correctness' by Conservatives and liberals who see it as a form of cultural coercion.

\section{DOMESTIC VIOLENCE}

Until the 1970s the existence of widespread violence by men against their female partners was scarcely recognised. It was almost impossible for women 
to persuade the police to prosecute in such cases. Furthermore, it was recognised that many women were suffering systematic violence but were trapped by circumstances - usually poverty and responsibility for children - and so could not escape.

These problems were attacked on two fronts. The first was to force the police to accept that domestic violence is a serious crime and to begin prosecutions. This campaign has yielded results and all police forces now have special domestic violence units. The second problem - women being trapped in a cycle of violence - was tackled by the opening of a network of refuges. In these 'safe' houses women and their children were able to escape from violent partners, their location being kept secret. Social and voluntary workers who are attached to these refuges are also able to attempt to find long-term solutions for the women.

\section{RAPE}

Legislative action is not required to strengthen protection against rape. The problem has been that too few cases have reached successful prosecution. The reasons for this are that:

- Women are constrained from reporting rape because they have feared they will not be treated sympathetically by the police.

- It is difficult to prove a charge of rape, especially when the defence is that the woman consented.

- Also in cases where consent is the main issue, women may find crossexamination in a trial a gruelling experience.

- In cases where the alleged rapist is a close friend, perhaps boyfriend (socalled 'date rape') it is especially difficult to secure a conviction.

- Wives have long claimed that it is possible to be raped by one's own husband. Until recently courts did not accept this.

Considerable progress has been made. Many police forces now have special rape units and officers trained to deal with women. In court women receive some protection by judges when giving evidence, especially when they may be crossexamined by the alleged rapist. The importance of date rape has now been recognised and it has become possible for husbands to be convicted of rape.

Nevertheless, women's campaigners continue to argue that rape is not taken as seriously as other crimes by either the police or the courts. This involves a change in attitudes, rather than any change in the law. In particular, it is argued that the past life of a woman should not be taken into consideration when she has accused a man of rape. 


\section{POSITIVE DISCRIMINATION}

Women are still considered to be suffering from discrimination. This occurs especially in employment. The law says that discrimination must not occur, but it is happening in subtle ways which avoid prosecution. The main concern is the so-called glass ceiling which is said to exist in many occupations, mainly the professions. The glass ceiling theory says that there is a level of promotion above which women find it very difficult to rise. The main culprits are said to be law, medicine, teaching, business and government.

The more extreme campaigners suggest that the answer to the glass ceiling is positive discrimination. Such a scheme requires that quotas should be established, so that a minimum proportion of women should be promoted to higher levels. This is, of course, a highly controversial proposal as it is suggested that some 'inferior' women may be promoted simply to fulfil a quota. Supporters, on the other hand, claim that positive discrimination will change the 'culture' in many organisations. With better opportunities, more able women will enter such professions so that the quotas will be filled by able people.

\section{POLITICS AND PARLIAMENT}

Just as it was assumed by the suffragettes that obtaining votes for women would lead to further examples of emancipation, modern campaigners see increased participation of women in politics as vital for the movement. The election of Margaret Thatcher as Conservative leader in 1975, and then as Prime Minister in 1979, may have been a key development. However, women's groups tended to disown her, partly because she was extremely unpopular in some sections of the community and partly because she refused to champion any women's causes.

Attention since has centred on having more women elected to parliament. Aided by a Labour party policy of insisting on more women candidates in winnable seats, a breakthrough seemed to have been made in 1997. A total of 120 women were elected, 101 of them from the Labour party. More women were also seen in the cabinet and by 2001 there were 7 and many more in junior ministerial posts. In 2001 fewer women were elected, but the number remains high. Women do play a key role in politics - far more than previously.

There remain some issues in politics. In particular the rules and procedures of parliament are considered unsympathetic to women MPs. Long hours, a lack of childcare facilities and the sheer nature of the job which involves much 
travelling, does not lend itself to motherhood. It is hoped that proposed reforms to the House of Commons in 2002 will address some of these concerns.

There is also lack of a specific cabinet post which deals with women's issues. There is a junior minister in charge of policy for women, but the fact that it is a junior post indicates how low it is on the political agenda.

\section{SAMPLE QUESTIONS}

1 Why has it proved so difficult in modern times to advance the cause of women's rights?

2 What are the main legislative and non-legislative initiatives since the 1960s which have been designed to raise the status of women?

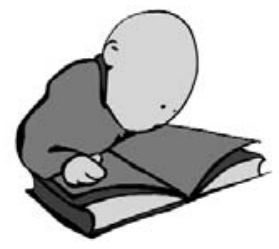

